\title{
A cross-sectional study among Polish hunters: seroprevalence of hepatitis $E$ and the analysis of factors contributing to $\mathrm{HEV}$ infections
}

\author{
Anna Baumann-Popczyk ${ }^{1}$ Bartłomiej Popczyk ${ }^{2,3} \cdot$ Elżbieta Gołąb $^{4}$. \\ Wioletta Rożej-Bielicka ${ }^{4} \cdot$ Małgorzata Sadkowska-Todys ${ }^{1}$
}

Received: 18 March 2017 / Accepted: 24 July 2017 / Published online: 3 August 2017

(c) The Author(s) 2017. This article is an open access publication

\begin{abstract}
Hepatitis E virus (HEV) is known as zoonotic agent. The main reservoirs of HEV in Europe are pigs, wild boars, and deer. Hunting activity is considered to be a risk factor for HEV infection. We conducted a crosssectional study among 1021 Polish hunters. To understand socio-demographic characteristics of this population and to gather information on potential exposures, all participants completed a questionnaire. Commercial immunoassays were employed to estimate seroprevalence anti-HEV. Samples with confirmed positive result of anti-HEV IgM were examined for HEV RNA. Anti-HEV IgG were identified in 227 people, $22.2 \%$ of the studied group. Seroprevalence among the studied hunters was associated with age $\geq 65$ [adjusted prevalence ratio (aPR) 1.6, $p=0.037$ ), living in a house (aPR 1.54, $p=0.013$ ), professional contact with farm animals (aPR 1.09, $p=0.01$ ), and consumption of stewed offal (aPR 1.61, $p=0.00$ ). Washing hands after disembowelment was linked to lower seroprevalence (aPR $0.53 ; p=0.00$ ). Lower prevalence of anti-HEV IgG among hunters living in cities was associated with age: $35-49$ (aPR 0.52, $p=0.011$ ) and 50-64 (aPR 0.93, $p=0.58$ ), living in a house (aPR 1.58, $p=0.002$ ) and owning a cat (aPR $0.58, p=0.042)$. Among
\end{abstract}

Anna Baumann-Popczyk

abaumann@pzh.gov.pl

1 Department of Epidemiology, National Institute of Public Health-National Institute of Hygiene, Chocimska str 24, 00-791 Warsaw, Poland

2 Department of Genetic and Animal Breeding, Faculty of Animal Science, University of Life Sciences, Warsaw, Poland

3 Polish Hunting Association, Warsaw, Poland

4 Department of Parasitology, National Institute of Public Health-National Institute of Hygiene, Warsaw, Poland hunters living in rural areas, seropositivity was associated with contact with farm animals (aPR 1.66, $p=0.013$ ) and consumption of stewed offal (aPR $1.81 ; p=0.001$ ). Contrary to initial assumptions, it was concluded that hunting was of significantly lesser importance than other factors. Due to the high level of HEV seroprevalence identified, we recommend conducting a large-scale study in the general population of Poland.

Keywords Epidemiology $\cdot$ Foodborne viruses . Zoonosis $\cdot$ Hunters $\cdot$ Hepatitis E (HEV)

\section{Introduction}

The hepatitis E virus (HEV) is an important human pathogen that is distributed worldwide [1]. In the last few years, HEV has been considered as an emerging infection or, by some researches, as a re-emerging disease [2]. Hepatitis E virus (HEV) is a non-enveloped RNA virus in the genus Orthohepevirus in the family Hepeviridae. Genotypes 1 (HEV-1) and 2 (HEV-2) cause infections in developing countries. Those infections are restricted to humans and transmitted by the oral-fecal route mainly through contaminated water [1]. Genotypes 3 (HEV-3) and 4 (HEV-4) have a wider host range, including humans and various animal species [3]. It was proved that those genotypes cause sporadic cases of hepatitis $\mathrm{E}$ in humans, mostly through zoonotic transmission or consumption of contaminated food [3, 4]. Alternative modes of transmission of minor epidemiological importance, such as blood transfusion [5] and organ transplantation [6, 7], were also reported. HEV-3 genotypes were found to be responsible for most autochthonous HEV infections in Europe, and to the lesser extent, infections with HEV-4 were also noted $[8,9]$. 
Diseases caused by HEV genotypes present clinical features similar to those occurring during infections caused by other hepatitis viruses. The course of infection can involve a wide range of clinical manifestations, from asymptomatic or subclinical to acute liver failure [10]. Chronic infections with HEV-3 and HEV-4 were found in immunocompromised patients, such as solid organ transplant recipients and HIV carriers [11]. Extra-hepatic manifestations, such as haematological and neurological disorders, kidney injuries, or acute pancreatitis, can also be associated with the HEV infection [12].

Seroprevalence of HEV in Europe in human ranges from 0.6 to $52.5 \%$, depending on the country, study group, and type of diagnostic test $[8,13]$. Domestic pig, wild boar, and deer were identified as major reservoirs of zoonotic HEV in Europe in many studies [3]. The highest HEV seroprevalence, ranging from 30 to $98 \%$, was observed in swine herds [14], whilst among tested wild boars, it reached the maximum of $47.2 \%$ [15]. HEV-3 was isolated from infected swine and wild boars [3]. Occupational exposure to swine [applying to veterinarians, slaughterhouse workers, and farmers) is associated with higher prevalence of anti-HEV $\mathrm{IgG}$, what supports the zoonotic nature of HEV infections [16].

Although HEV infections are a cause for concern, the epidemiological situation is not under comprehensive control in Poland. This may be due to the lack of routine HEV diagnostics and low awareness among doctors of this virus and infection, which often takes nonspecific or asymptomatic course. In Poland, hepatitis E is a notifiable disease listed among "infections caused by other hepatitis viruses"- there is no case definition of hepatitis E. In the years 2014-2015, eight human cases of hepatitis $E$ were notified and most of them were laboratory confirmed outside of Poland (source: Department of Epidemiology at NIPH-PZH). There was found only one case report on hepatitis E diagnosed in Poland in foreign student residing in north-eastern part of our country [17].

The precise data on seroprevalence of HEV in the general population in Poland are limited. However, several results of HEV seroprevalence surveys have been published. One of them was conducted among Indian citizens who studied in Polish university located in eastern part Poland and serological markers of HEV infection were detected in $12(26.7 \%)$ tested students [18]. In the study conducted in the west-central Poland IgG, anti-HEV was found in $15.9 \%$ within 182 tested serum samples [19]. In the above mentioned region, $50.2 \% \mathrm{HEV}$-positive results were obtained in a study group consisted of HIV-infected persons and blood donors [20].

There are evidences that HEV circulates among domestic pigs, wild boar, and this species should be considered as important reservoirs of the virus in Poland [21-23].
Population of wild boar in Poland is growing, from 120,000 in 1999/2000-264,000 in 2015/2016, and currently, it is one of the most intensively hunted species in our country (Central Statistical Office, 2016). As a result of frequent and direct contact with infected wild animals, hunters are potentially exposed to zoonotic pathogen [24]. According to data from the Polish Hunting Association, 10\% of its members work in agriculture, including pig farming, which is a known risk factor for HEV infection [16].

In Europe, there have been reports on the increasing prevalence of HEV among people as well as an increasing number of reports on negative health consequences of being infected $[9,11]$. Therefore, the need to investigate the epidemiological profile of HEV in Poland is a necessity.

The purpose of this study was to assess HEV seroprevalence in the population of Polish hunters. Furthermore, the study aimed to provide in-depth analysis of the data gathered in previous study to identify factors associated with the prevalence of anti-HEV IgG antibodies in the examined population.

\section{Materials and methods}

\section{Study design}

The presented cross-sectional study was carried out between October 2010 and July 2012 among Polish hunters. The study was a part of a larger project financed by the Ministry of Science and Higher Education (N N404 520038) entitled "Occurrence and prevalence of selected zoonotic agents: Echinococcus multilocularis, Trichinella spiralis and hepatitis E virus (HEV) in the population of Polish Hunters" [25].

For the purpose of this study, a hunter was defined as a member of the Polish Hunting Association (PHA), in accordance with Polish law (the Hunting Act of October 13, 1995). The study was approved by Bioethics Commission in the National Institute of Public Health-National Institute of Hygiene in Warsaw (Opinion no 1/2009 of 15.10.2009).

Authors of the study invited hunters from all regional units of the Polish Hunting Association. The study participants' recruitment was conducted through convenience sampling, in line with guidelines previously described by Sadkowska-Todys et al. [25]. Participation in the study was voluntary. Potential participants were provided with information on the aim of the study, as well as a leaflet about the study and pathogens that they might be tested for. Written consent was obtained from all recruited participants. Socio-demographic characteristics (e.g., age, gender, and place of residence) and information on potential exposures (e.g., area of hunting, length of membership 
of the PHA, preparation and consumption of wild game meat, etc.) were collected using structured questionnaires administered through face-to-face interviews. The study questionnaire was designed in the Department of Epidemiology after consultation with the PHA and piloted among 91 hunters. Information on history of exposures was assessed through simple closed questions. Previous exposures related to hunting were ranked based on hunting activities or preferences.

\section{Data on general hunter population in Poland}

The Central Statistical Office of Poland (Forestry 2012) and the PHA provided data on the population and characteristic of Polish hunters.

\section{Laboratory testing}

To identify serological markers of infection, in our study, we used two commercial immunoenzymatic tests: recomWell HEV IgG and recomWell HEV IgM (versions available in Poland in 2011; Mikrogen, Neuried, Germany). Each anti-HEV IgM antibody positive EIA test result was confirmed with the recomLine HEV IgM/IgG immunoblot test (version available in Poland in 2011; Mikrogen, Neuried, Germany).

All positive samples in the immunoblot test were examined for the presence of HEV RNA. The real-time PCR reaction was performed using the commercial ampliCube HEV 2.0 set (Mikrogen, Neuried, Germany).

Tests were carried out in accordance with the manufacturer's instructions.

\section{Statistical analysis}

Prevalence of anti-HEV antibodies (IgG and IgM) was calculated and the exact binomial distribution was used to calculate $95 \%$ confidence intervals (CI).

Possible predictors of anti-HEV seropositivity were assessed by calculating prevalence ratio (PR) and adjusted prevalence ratio (aPR) and their corresponding 95\% confidence intervals (CI), using univariable and multivariable log binomial regressions, respectively.

In this study, a case was defined by the positive result of recomWell IgG. The final multivariable model was built stepwise using results of univariate analysis (where $p \leq 0.2$ ). In addition, to differentiate specific predictors for infection between urban and rural areas, the studied group was stratified by place of residence. Data were analyzed by the statistical package Stata 10.

\section{Results}

\section{Characteristics of the study group}

A total number of 1021 from 1041 recruited participants met our case definition of a hunter. The study sample represented $0.9 \%$ of the hunters' population in Poland. Participants were recruited through convenience sampling. Therefore, the first stage of the study compared selected features of the examined group with the entire hunters' population. The general characteristics, such as gender, age or length of membership in the PHA, were the same or very similar to those in the general hunter population in Poland (Table 1).

Participants' age ranged from 19 to 85 years (mean 49.5 years). The most frequent group of respondents were persons aged 51-60. The average age was higher among men (mean 49.8, median age 51 years) than among women (mean 37.2 , median 30 years). However, those differences were not statistically significant.

\section{Prevalence of HEV in study group}

Anti-HEV IgG were found in 227 people, which represented $22.2 \%$ of the studied group (95\% CI 19.7-24.9).

Anti-HEV IgM were detected in 43 individuals in recomWell IgM test (4.21\% of the examined group of hunters). Using recomLine IgM/IgG, anti-HEV IgM were found in five of the hunters. This represented $0.5 \%$ of the entire studied group. HEV RNA was not detected in the serum of persons with confirmed anti-HEV IgM. None of those persons had symptoms of acute hepatitis.

\section{Factors associated with anti-HEV IgG seroprevalence}

Significant differences in the number of anti-HEV IgG positive cases in the studied group were observed depending on the province. The highest seroprevalence was among hunters who lived in Opolskie (42.4\%), Wielkopolskie (30.5\%), and Pomorskie (31.9\%). The lowest was recorded among people living in Kujawsko-Pomorskie (10\%), Łódzkie (11.2\%), and Świętokrzyskie (13.9\%) (Fig. 1).

Multivariable regression analysis confirmed that the prevalence of HEV infection increased with age. People aged over 65 years had anti-HEV IgG significantly more frequently than those who were younger [adjusted prevalence ratio (aPR) 1.6; 95\% CI 1.03-2.49]. The percentage of HEV positivity was $40 \%$ higher among hunters living in a house than those living in an apartment (aPR 1.4; 95\% CI 1.09-2.01). Those who declared direct contact with farm animals, mainly pigs, had anti-HEV antibodies $40 \%$ more often (aPR 1.41; 95\% CI 1.09-1.83). Moreover, washing hands immediately after disembowelment reduced the risk of infection (aPR 0.53; 95\% CI 0.37-0.74). A higher 
Table 1 Comparison of participants to the source population of Polish hunters by gender, age category, and place of residence

\begin{tabular}{|c|c|c|c|c|}
\hline \multirow[t]{2}{*}{ Characteristics } & \multicolumn{2}{|c|}{ Source population $^{\mathrm{a}}$} & \multicolumn{2}{|c|}{ Participants } \\
\hline & $N$ & $\%$ & $N$ & $\%$ \\
\hline Total & 111,948 & 100 & 1021 & 0.9 \\
\hline \multicolumn{5}{|l|}{ Sex } \\
\hline Female & 2614 & 2.3 & 23 & 2.3 \\
\hline Male & 109,334 & 97.7 & 998 & 97.7 \\
\hline \multicolumn{5}{|l|}{ Age category (years) } \\
\hline$>30$ & 9101 & 8.1 & 91 & 8.9 \\
\hline $31-40$ & 19,602 & 17.5 & 182 & 17.8 \\
\hline $41-50$ & 21,069 & 18.8 & 217 & 21.3 \\
\hline $51-60$ & 26,420 & 23.6 & 312 & 30.6 \\
\hline $61-70$ & 23,845 & 21.3 & 181 & 17.7 \\
\hline$<71$ & 11,766 & 10.5 & 38 & 3.7 \\
\hline nd & 146 & 0.1 & - & - \\
\hline \multicolumn{5}{|c|}{ Length of membership of the PHA (in years) } \\
\hline $0-3$ & 15,079 & 13.5 & 65 & 6.4 \\
\hline $4-10$ & 23,050 & 20.6 & 191 & 18.7 \\
\hline $11-20$ & 23,957 & 21.4 & 247 & 24.2 \\
\hline $21-30$ & 23,509 & 21 & 278 & 27.2 \\
\hline$>31$ & 26,140 & 23.4 & 240 & 23.5 \\
\hline nd & 213 & 0.2 & - & - \\
\hline \multicolumn{5}{|l|}{ Province } \\
\hline Dolnośląskie & 8932 & 8 & 60 & 5.9 \\
\hline Kujawsko-Pomorskie & 6537 & 5.8 & 50 & 4.9 \\
\hline Lubelskie & 6870 & 6.1 & 149 & 14.6 \\
\hline Lubuskie & 4925 & 4.4 & 6 & 0.6 \\
\hline Łódzkie & 5520 & 4.9 & 27 & 2.6 \\
\hline Małopolskie & 6896 & 6.2 & 48 & 4.7 \\
\hline Mazowieckie & 13,902 & 12.4 & 117 & 11.5 \\
\hline Opolskie & 3550 & 3.2 & 59 & 5.8 \\
\hline Podkarpackie & 6756 & 6 & 34 & 3.3 \\
\hline Podlaskie & 4515 & 4 & 44 & 4.3 \\
\hline Pomorskie & 6953 & 6.2 & 44 & 4.3 \\
\hline Śląskie & 6512 & 5.8 & 38 & 3.7 \\
\hline Świętokrzyskie & 3663 & 3.3 & 36 & 3.5 \\
\hline Warmińsko- Mazurskie & 6886 & 6.2 & 45 & 4.4 \\
\hline Wielkopolskie & 11,575 & 10.3 & 105 & 10.3 \\
\hline Zachodniopomorskie & 7956 & 7.1 & 159 & 15.6 \\
\hline
\end{tabular}

${ }^{a}$ Members of the Polish Hunting Association in 2011

seroprevalence was also found among hunters who hunted wild boars three times a year (on a five-point scale) compared to those who hunted wild boar once a year. Consuming stewed offal, e.g., liver, was linked to higher seroprevalence in the studied group (aPR 1.61; 95\% CI 1.27-2.03) (Table 2).

Based on our preliminary results, we stratified the examined hunters by place of residence to identify specific risk factors for urban and rural areas.
Prevalence of anti-HEV IgG among hunters living in cities was also linked with age. The frequency of HEV IgG antibodies was significantly lower among hunters aged 35-49 and 50-64 than hunters aged up to 34 years (aPR 0.52 ; 95\% CI 0,31-0.86; aPR 0.66; 95\% CI 0.42-1.02). Participants from urban areas were $68 \%$ more likely to test positive with anti-HEV IgG if they lived in a house rather than an apartment (aPR 1.68; 95\% CI 1.22-2.31). The significantly lower percentage of HEV-positive persons was observed among hunters who lived in a city and hunted abroad (aPR 0.54; 95\% CI 0.3-0.95). A higher HEV seroprevalence was observed among hunters who preferred to hunt wild boar. However, a lower seroprevalence was observed among cat owners (aPR 0.58; 95\% CI 0.34-0.99) (Table 3).

The seroprevalence among hunters living in rural areas increased with age; however, this was not statistically significant $(p=0.098)$. The multivariable analysis indicated that people living in rural areas who reported direct contact with farm animals had anti-HEV IgG $66 \%$ more frequently than those hunters who did not have similar contact (aPR 1.66; 95\% CI 1.12-2.46). Moreover, the seroprevalence of antiHEV IgG among people who prepared and consumed stewed offal was significantly higher (aPR 1.81; 95\% CI 1.29-2.53). Results of univariable analysis indicated that being a farmer may have a significant impact on the positive HEV-IgG test result. However, multivariable analysis did not confirm the above results (PR 1.68; 95\% CI 1.12-2.52 vs. aPR 1.24; 95\% CI 0.77-1.98) (Table 4).

\section{Discussion}

This is the first large-scale study considering HEV seroprevalence in Poland. Hunters are a fairly large group which represents a cross section of Polish society. However, this particular group is also occupationally exposed to HEV reservoirs and consists mainly of men, thus preventing the extrapolation of the obtained results to the general population. The advantage of this study is that the examined population constitutes nearly $1 \%$ of the source population.

Anti-HEV IgG was identified in 227 Polish hunters ( $22.2 \%$ of the examined group). However, in the publication by Sadkowska-Todys et al. which concerned the same study group, seroprevalence was assessed at $20.3 \%$ [25]. Discrepancies between those results are associated with different case study definitions used in the analysis. Nevertheless, the difference between seroprevalence was minor. Other studies performed among the general population and blood donors found higher anti-HEV seroprevalence in a group of hunters compared to non-hunters [26-28]. Authors of those studies hypothesized that hunting activities can be associated with HEV infection. Hunting can 


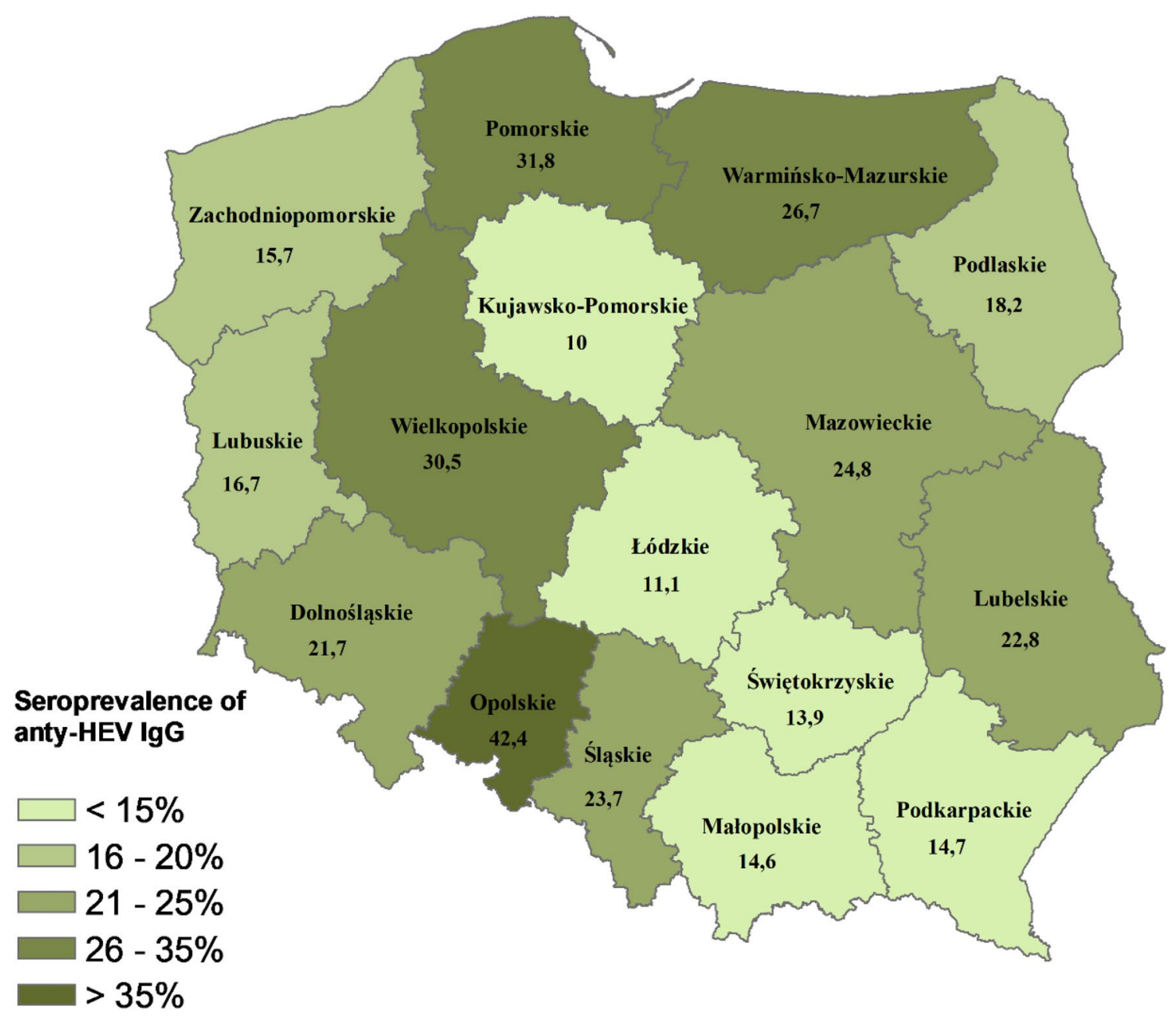

Fig. 1 Seroprevalence of anti-HEV IgG among hunters by the province of residence

result in direct contact with wild boars, considered to be important reservoirs of HEV infections in humans. HEV infection can occur during evisceration of an infected animal, through contact with its blood or faeces. Butchers and slaughterhouse workers were proven to have higher seroprevalence compared with the general population, what can confirm that cutting up carcasses might be a risk factor of HEV infection [29]. These hypotheses are supported by the appearance of HEV RNA in wild boars' sera and faeces in many European countries: Belgium [30], Estonia [31], Germany [32, 33], Netherlands [34], Slovenia [35], Sweden [36], Italy [37], and Portugal [38]. Moreover, there was also a chronic HEV-3 infection in wild boars described in Germany. It was observed that viremia and fecal excretion lasted more than 5 months [39]. The percentage of seroprevalence in wild boars in Europe amounts from 10.2\% in Italy [40] to $47.2 \%$ in Spain [15]. Hunting traditions and habits can also lead to an infection [38]. According to the Hunting Act of October 13, 1995, after shooting their first animal, new hunters involve in a traditional ceremony called the "baptism of fire", during which the hunter's forehead is being covered with blood.

Other conducted studies did not identify hunting activity as an important risk factor. Our result of seroprevalence of anti-HEV $\operatorname{IgG}$ is similar to the one obtained among German hunters (21\%) after applying the same test. This study revealed no significant difference of HEV seroprevalence between the examined group of hunters and the general population (21 vs. 17\%) [41]. Unfortunately, such comparison cannot be made in the presented study due to lack of research among general population in Poland. Other studies hypothesize that professional contact with swine is a stronger risk factor than hunting [31, 42]. Similarly, our study also proved that direct contact with farm animals is an important factor influencing the prevalence of anti-HEV IgG. Hunters that had professional contact with farm animals tested positive with anti-HEV IgG more often than the reference group by $66 \%$. This result is consistent with the knowledge that domestic pigs are proven HEV reservoirs in industrialized countries [13]. Teixeira et al. found 
Table 2 Seroprevalence of anti-HEV IgG and risk factors associated with HEV infection among Polish hunters

\begin{tabular}{|c|c|c|c|c|c|c|c|}
\hline Variable & No. of subjects & No. of positive (\%) & $95 \% \mathrm{CI}$ & PR $(95 \%$ CI $)$ & $p$ & APR $(95 \% \mathrm{CI})$ & $p$ \\
\hline \multicolumn{8}{|l|}{ Age (years) } \\
\hline$\leq 34$ & 174 & $36(20.69)$ & $14.93-27.47$ & Reference & & Reference & \\
\hline $35-49$ & 294 & $58(19.73)$ & $15.33-47.43$ & $0.95(0.66-1.38)$ & 0.802 & $0.8(0.63-1.01)$ & 0.060 \\
\hline $50-64$ & 442 & $99(22.40)$ & $18.59-26.58$ & $1.08(0.77-1.52)$ & 0.646 & $0.91(0.67-1.22)$ & 0.494 \\
\hline$\geq 65$ & 111 & $34(30.63)$ & $22.23-40.09$ & $1.48(0.99-2.21)$ & 0.057 & $1.6(1.03-2.49)$ & 0.037 \\
\hline \multicolumn{8}{|c|}{ Type of accommodation } \\
\hline Flat & 315 & $51(16.2)$ & $12.30-20.73$ & Reference & & Reference & \\
\hline House & 706 & $176(24.9)$ & $21.78-28.29$ & $1.54(1.61-2.04)$ & 0.003 & $1.48(1.09-2.01)$ & 0.013 \\
\hline \multicolumn{8}{|l|}{ Occupation } \\
\hline $\begin{array}{l}\text { Employment in the } \\
\text { private sector }\end{array}$ & 84 & $15(17.9)$ & $10.35-27.74$ & Reference & & Reference & \\
\hline Unemployed & 6 & $3(50)$ & $11.81-88.19$ & $2.8(1.11-7.04)$ & 0.029 & $1.86(0.53-6.58)$ & 0.339 \\
\hline Retiree and pension & 193 & $49(25.4)$ & $19.41-32.14$ & $1.42(0.85-2.39)$ & 0.183 & $1.08(0.6-1.95)$ & 0.799 \\
\hline Other & 280 & $53(18.9)$ & $14.51-24.02$ & $1.06(0.63-.78)$ & 0.826 & $1.03(0.6-1.76)$ & 0.926 \\
\hline Woodsman & 167 & $37(22.2)$ & $16.10-29.22$ & $1.24(0.72-2.13)$ & 0.433 & $0.98(0.56-1.72)$ & 0.941 \\
\hline Scientific worker & 26 & $7(26.9)$ & $11.57-47.79$ & $1.51(0.69-3.29)$ & 0.303 & $1.46(0.66-3.27)$ & 0.361 \\
\hline Working in PHA & 55 & $9(16.4)$ & $7.76-28.80$ & $0.92(0.43-1.95)$ & 0.820 & $0.86(0.38-1.93)$ & 0.702 \\
\hline Farmer & 57 & $19(33.3)$ & $21.40-47.06$ & $1.87(1.04-3.36)$ & 0.037 & $1.22(0.66-2.27)$ & 0.531 \\
\hline Student & 12 & $2(16.7)$ & $2.09-48.41$ & $0.93(0.24-3.58)$ & 0.920 & $0.72(0.19-2.73)$ & 0.627 \\
\hline Company owner & 114 & $28(24.6)$ & $16.98-47.16$ & $1.38(0.79-2.41)$ & 0.265 & $1.06(0.58-1.95)$ & 0.853 \\
\hline Army and police & 21 & $5(23.8)$ & $8.22-47.16$ & $1.33(0.55-3.25)$ & 0.527 & $0.88(0.28-2.79)$ & 0.816 \\
\hline \multicolumn{8}{|c|}{ Professional contact with animals $(n=952)$} \\
\hline No & 796 & $154(19.3)$ & $16.89-22.53$ & Reference & & Reference & \\
\hline Yes & 156 & $71(45.5)$ & $25.54-38.06$ & $1.61(1.27-2.04)$ & 0 & $1.09-1.83$ & 0.01 \\
\hline \multicolumn{8}{|c|}{ Hunting abroad in the last 14 years } \\
\hline No & 890 & $200(22.5)$ & $19.77-25.36$ & Reference & & Reference & \\
\hline Yes & 129 & $22(17.1)$ & $11.01-24.67$ & $0.76(0.51-1.13)$ & 0.176 & $0.45-1.12$ & 0.134 \\
\hline \multicolumn{8}{|c|}{ Hand washing after disembowelling $(n=901)$} \\
\hline No & 30 & $10(33.3)$ & $17.29-52.81$ & Reference & & Reference & \\
\hline Yes & 871 & $186(21.4)$ & $18.68-24.23$ & $0.64(0.38-1.09)$ & 0.094 & $0.37-0.74$ & $\mathbf{0 . 0 0 0}$ \\
\hline \multicolumn{8}{|c|}{ Cultivating the cereals $(n=1014)$} \\
\hline No & 738 & $154(20.9)$ & $18.00-23.98$ & Reference & & Reference & \\
\hline Yes & 276 & $72(26.1)$ & $21.00-31.69$ & $1.25(0.98-1.60)$ & 0.072 & $0.86-1.39$ & 0.507 \\
\hline \multicolumn{8}{|c|}{ Presence of rodents in the place of accomodation $(n=1012)$} \\
\hline No & 363 & $67(18.5)$ & $14.35-22.54$ & Reference & & Reference & \\
\hline Yes & 649 & $159(24.5)$ & $10.94-27.68$ & $1.33(1.03-1.71)$ & 0.029 & $0.84-1.48$ & 0.468 \\
\hline \multicolumn{8}{|c|}{ Average annual wild boars hunting (on a five-point scale) $(n=984)$} \\
\hline 1 & 101 & $17(16.8)$ & $10.12-25.58$ & Reference & & Reference & \\
\hline 2 & 130 & $37(28.5)$ & $20.90-37.04$ & $1.69(1.01-2.82)$ & 0.044 & $1.36(0.79-2.35)$ & 0.271 \\
\hline 3 & 171 & $37(21.6)$ & $15.71-28.57$ & $1.29(0.77-2.16)$ & 0.343 & $1.66(1-2.75)$ & 0.054 \\
\hline 4 & 212 & $54(25.5)$ & $19.75-31.89$ & $1.51(0.93-2.47)$ & 0.098 & $1.45(0.88-2.4)$ & 0.152 \\
\hline 5 & 370 & $79(21.4)$ & $17.28-25.88$ & $1.27(0.79-2.04)$ & 0.327 & $1.17(0.72-1.9)$ & 0.551 \\
\hline \multicolumn{8}{|c|}{ Prepared and consumed stewed offal $(n=985)$} \\
\hline No & 839 & $176(21)$ & $18.27-23.89$ & Reference & & Reference & \\
\hline Yes & 146 & $45(30.8)$ & 23.45-38.99 & 1.47 (1.11-1.94) & 0.006 & $1.611 .27-2.03$ & 0.000 \\
\hline
\end{tabular}

Significant $P$ values $(<0.05)$ are in bold

PR (prevalence ratio), APR (adjusted APR for age, place of accommodation, occupation, professional contact with animals, hunting abroad, hand washing after evisceration, cultivating the cereals, presence of rodents in the place of accommodation, prepared, and consumed stewed offal) 
Table 3 Seroprevalence of anti-HEV IgG and risk factors associated with HEV infection among hunters living in urban area

\begin{tabular}{|c|c|c|c|c|c|c|c|}
\hline Variable & No. of subjects & No. of positive (\%) & $95 \% \mathrm{CI}$ & PR $(95 \% \mathrm{CI})$ & $p$ & APR $(95 \% \mathrm{CI})$ & $p$ \\
\hline \multicolumn{8}{|c|}{ Age (years) $(n=598)$} \\
\hline$\leq 34$ & 74 & $18(24.3)$ & $14.93-27.47$ & Reference & & Reference & \\
\hline $35-49$ & 161 & $26(16.1)$ & $15.33-24.74$ & $0.67(0.39-1.14)$ & 0.133 & $0.52(0.31-0.86)$ & 0.011 \\
\hline $50-64$ & 272 & $54(19.9)$ & $18.59-26.58$ & $0.82(0.52-1.31)$ & 0.394 & $0.66(0.42-1.02)$ & 0.058 \\
\hline$\geq 65$ & 91 & $28(30.8)$ & $22.23-40.1$ & $1.27(0.77-2.1)$ & 0.363 & $0.93(0.58-1.51)$ & 0.754 \\
\hline \multicolumn{8}{|c|}{ Type of accommodation } \\
\hline Flat & 279 & $45(16.1)$ & $12.30-20.73$ & Reference & & Reference & \\
\hline House & 319 & $81(25.4)$ & $21.80-28.30$ & $1.58(1.14-2.19)$ & 0.007 & $1.68(1.22-2.31)$ & 0.002 \\
\hline \multicolumn{8}{|c|}{ Hunting abroad $(n=597)$} \\
\hline No & 510 & $113(22.2)$ & $20.10-25.71$ & Reference & & Reference & \\
\hline Yes & 87 & $12(13.8)$ & $11.01-24.67$ & $0.63(0.36-1.08)$ & 0.091 & $0.54(0.3-0.95)$ & $\mathbf{0 . 0 3 1}$ \\
\hline \multicolumn{8}{|c|}{ Average annual wild boars hunting (on a five-point scale) $(n=576)$} \\
\hline 1 & 61 & $8(13.1)$ & $10.12-25.58$ & Reference & & Reference & \\
\hline 2 & 75 & $18(24)$ & $20.90-37.03$ & $1.83(0.86-3.92)$ & 0.12 & $1.92(0.9-4.11)$ & 0.093 \\
\hline 3 & 105 & $21(20)$ & $15.71-28.57$ & $1.53(0.72-3.24)$ & 0.271 & $1.75(0.84-3.68)$ & 0.14 \\
\hline 4 & 122 & $34(27.9)$ & $19.75-31.89$ & $2.13(1.05-4.31)$ & 0.036 & $2.4(1.19-4.85)$ & $\mathbf{0 . 0 1 5}$ \\
\hline 5 & 213 & $42(19.7)$ & $17.28-25.88$ & $1.51(0.75-3.03)$ & 0.254 & $1.7(0.85-3.39)$ & 0.139 \\
\hline \multicolumn{8}{|c|}{ Having a cat $(n=585)$} \\
\hline No & 490 & $111(22.7)$ & $20.27-26.40$ & Reference & & Reference & \\
\hline Yes & 95 & $13(13.7)$ & $15.00-25.42$ & $0.61(0.36-1.03)$ & 0.063 & $0.58(0.34-0.99)$ & 0.042 \\
\hline
\end{tabular}

Significant $P$ values $(<0.05)$ are in bold

PR (prevalence ratio), aPR (adjusted aPR for age, place of accommodation, hunting abroad, average annual wild boars hunting, having a cat)

Table 4 Seroprevalence of anti-HEV IgG and risk factors associated with HEV infection among hunters living in rural area

\begin{tabular}{|c|c|c|c|c|c|c|c|}
\hline Variable & No. of subjects & No. of positive (\%) & $95 \% \mathrm{CI}$ & PR $(95 \% \mathrm{CI})$ & $p$ & $\operatorname{APR}(95 \% \mathrm{CI})$ & $p$ \\
\hline \multicolumn{8}{|c|}{ Age (years) $(n=423)$} \\
\hline$\leq 34$ & 100 & $18(18)$ & $11.03-26.95$ & Reference & & Reference & \\
\hline $35-49$ & 133 & $32(24.1)$ & $17.07-32.23$ & $0.27(0.8-2.24)$ & 0.27 & $1.34(0.83-2.18)$ & 0.24 \\
\hline $50-64$ & 170 & $45(26.5)$ & $20.01-33.77$ & $0.121(0.91-2.4)$ & 0.121 & $1.32(0.83-2.1)$ & 0.25 \\
\hline$>=65$ & 20 & $6(30)$ & $11.89-54.28$ & $0.205(0.76-3.68)$ & 0.205 & $1.36(0.64-2.89)$ & 0.428 \\
\hline \multicolumn{8}{|c|}{ Professional contact with animals $(n=423)$} \\
\hline No & 301 & $56(18.6)$ & $14.37-23.50$ & Reference & & Reference & \\
\hline Yes & 122 & $45(36.9)$ & $28.33-46.09$ & $0(1.43-2.77)$ & $\mathbf{0 . 0 0 0}$ & $1.66(1.12-2.46)$ & 0.013 \\
\hline \multicolumn{8}{|c|}{ Cultivating the cereals $(n=420)$} \\
\hline No & 259 & $56(21.6)$ & $17.98-23.98$ & Reference & & Reference & \\
\hline Yes & 161 & $45(28)$ & $21.07-31.69$ & $0.138(0.93-1.82)$ & 0.138 & $1.05(0.73-1.51)$ & 0.819 \\
\hline \multicolumn{8}{|c|}{ Prepared and consumed stewed offal $(n=407)$} \\
\hline No & 336 & $71(21.1)$ & $16.90-25.89$ & Reference & & Reference & \\
\hline Yes & 71 & $28(39.4)$ & $28.03-51.75$ & $0.001(1.31-2.67)$ & 0.001 & $1.81(1.29-2.53)$ & 0.001 \\
\hline \multicolumn{8}{|c|}{ Farmer $(n=421)$} \\
\hline No & 370 & $82(22.2)$ & $18.03-26.74$ & Reference & & Reference & \\
\hline Yes & 51 & $19(37.3)$ & $24.12-51.92$ & $0.012(1.12-2.52)$ & 0.012 & $1.24(0.77-1.98)$ & 0.386 \\
\hline
\end{tabular}

Significant $P$ values $(<0.05)$ are in bold

PR (prevalence ratio), aPR (adjusted aPR for age, professional contact with animals, cultivating the cereals, prepared, and consumed stewed offal farmer)

significantly higher anti-HEV IgG seroprevalence in workers occupationally exposed to swine compared to general population [29]. It was also established that the frequency of anti-HEV appearance is higher among veterinarians and pig farmers [43-47]. However, this was not observed among Finnish veterinarians specializing in swine diseases [48]. 
Although regional differences in HEV seroprevalence between Polish provinces were observed in this study, they are difficult to interpret. In Poland, regional discrepancy in seroprevalence was determined in the wild boar population [21]. However, those differences were not reflected in the seroprevalence among hunters. Furthermore, they can be caused by a number of factors, e.g., eating habits or age distribution of the examined population. Nevertheless, those findings should be analyzed with caution due to the small number of participants and the convenience sampling applied in this study.

In our study, the highest frequency of the antibodies occurrence was observed in the oldest age group (over 65 years $)(30.6 \%, p$ value $=0.013)$. The prevalence among countryside residents increased with age, but this correlation was not statistically significant $(p=0,098)$. Those results were in line with other seroprevalence reviews conducted within the general population, particularly in blood donors' groups [49-51]. Higher seroprevalence among older people can be a consequence of longer potential exposure. However, in some studies, the relation between age and frequency of HEV infection was not established [27]. We observed that among hunters living in cities, higher seroprevalence was in the youngest (24.3\%) and the oldest (30.8\%) age groups. Increased seroprevalence in the younger group could be an indirect evidence of hunting as a risk factor. City residents rarely have professional contact with domestic pigs, thus hunting could have the strongest influence on the seroprevalence in this group. It could also be hypothesized that higher seroprevalence can result from increased hunting frequency among younger hunters.

This study revealed higher seroprevalence of HEV among men compared to women (22.5 and 8.3\% respectively). However, this difference was not statistically significant due to a limited number of women participants. Higher seroprevalence observed among men in comparison with women was also found in other studies among blood donors and other groups [51-53].

Significant differences were observed depending on the type of accommodation. Participants living in houses were more likely to have anti-HEV antibodies than those who lived in an apartment. Hypothetically, this could be related to owning private springs or wells when living in a house. In a study conducted in France, possible risk factors among the indigenous cases included water consumption from a personal water supply [54].

Zoonotic transmission of HEV is proven to be directly related to consumption of meat, offal, and other products from infected animals. HEV transmission through consumption of wild boar and deer meat has been reported in Japan [55-57], Spain [58], and Italy [59]. Case-control study conducted in Germany found that offal and wild boar meat consumption was a risk factor for hepatitis $\mathrm{E}$ infection [60]. Furthermore, consumption of game meat and offal has been associated with higher seroprevalence of HEV infection in humans in other studies [26, 51]. One of the determinants identified in the present study as being related to higher HEV seroprevalence was preparing and consuming stewed offal of hunted animals (aPR 1.6; 95\% CI 1.27-2.03). Thermal processing of meat/offal plays a significant role in viral inactivation. To completely inactivate $\mathrm{HEV}$, pork products need to be heated to an internal temperature of $71^{\circ} \mathrm{C}$ for $20 \mathrm{~min}$ [61]. The present study did not establish any relation between consumption of raw or grilled meat/offal and higher HEV seroprevalence. This could be explained by the fact that there is no tradition of eating wild boar meat/offal without proper heat treatment in Poland (although sausages and ham smoked in low temperatures are popular in some regions). This study did not reveal any connection between consumption of smoked products, regardless of the temperature of the process (cold/hot smoking). However, minced raw meat from roe, deer, and fallow deer is often consumed. Since no specific antibodies against HEV were found in the studies focusing on Cervidae population in Poland, it might not be an important factor for HEV sources [21].

The presented study also revealed determinants associated with lower seroprevalence in the studied group of hunters.

Owning a cat (aPR 0.58, 95\% CI 0.34-0.99) was found to be related with lower seroprevalence of anti-HEV among hunters living in cities. In the study by Lewis et al., conducted in England and Wales, $60 \%$ of cases of hepatitis E declared having pets [62]. An indirect evidence that cats could be a reservoir of HEV is a case of HEV infection in an owner of an anti-HEV-positive cat [63]. Moreover, specific anti-HEV antibodies were found in cats during other studies [64]. However, a research conducted among Austrian soldiers and civilians contradicts those findings. In this study, cat owners presented lower frequency of antiHEV than the reference group by $61 \%$ (OR $=0.61,95 \%$ CI 0.40-0.93) [65]. This is consistent with results of the present study. Another study conducted among pet veterinarians has shown that there are no significant differences in HEV seroprevalence between these professionals and general population (9.9 vs. 13.3\%) [66]. Owning a cat was also found to be a protective factor $(\mathrm{OR}=0.2 ; 95 \% \mathrm{CI}$ $0.06-0.73$ ) in case-control study conducted in Germany [60].

The presented study established a significant relation between washing hands after disembowelling carcasses and lower frequency of HEV seroprevalence (aPR 0.53; 95\% CI 0.37-0.74). These findings are consistent with previous observations by Schielke et al. HEV seroprevalence proved to be lower among hunters using gloves during disembowelment than among those who used gloves rarely or never 
(aPR 0.12; 95\% CI 0.02-0.8) [40]. Similarly, Chaussade et al. found that wearing boots at work by pig farm workers and forestry workers were associated with significantly lower seroprevalence of HEV (OR 0.45, $p=0.004$ ) [67]. The protective effect of gloves and proper hand hygiene during evisceration indirectly proves that direct contact with animal reservoirs could be a risk factor of HEV infection $[40,41]$. The lack of personal protection could mean a low awareness of exposure to potential infectious agents among those hunters. Implementing those simple protection measures can minimize the risk of an infection.

The appearance of only anti-HEV IgM indicates an active infection [68]. The hunters that tested positive for anti-HEV IgM did not report any symptoms indicating acute hepatitis. In addition, three of them were positive with both anti-HEV IgM and IgG. Although that HEV RNA has not been detected, an active asymptomatic infection cannot be excluded [69]. However, a study among German blood donors indicates that diagnostic window between identifying HEV RNA and the first detection of specific anti-HEV antibodies lasts from 8 to 48 days (depending on the test used) [70].

The results of this study should be interpreted in the context of its limitations. One of the main limitations is the classification of participants as cases based on the results from the EIA test-anti-HEV IgG, what can result in misclassification. Moreover, the study was conducted applying version of recomWell IgM and IgG test and recomLine IgM/IgG (Mikrogen, Germany) available in Poland in 2011. The tests were later improved to achieve higher sensitivity $[71,72]$. The present study bears the risk of underestimation of viremia in the examined group of hunters. Especially, only 5 of the 1021 studied hunters were tested for HEV RNA. Authors are aware that convenience sampling of participants provided lower representativeness of the study sample in the entire population of hunters in Poland. However, acquiring a large study group allowed to minimize the possible error. Another limitation of the study was volunteer bias. Although knowledge about HEV infection among hunters is small, this study also assessed the seroprevalence of other foodborne diseases. Hunters are usually familiar with risk factors associated with trichinellosis and echinococcosis and, therefore, could be more interested in participating in the study. Construction of the question included in our survey, which referred only to the general "wild game meat", did not enable to establish what species it actually indicated.

Due to high seroprevalence of HEV among hunters, a large-scale study in the general population and/or selected risk groups is recommended to estimate the actual scale of this problem in Poland. Results of this study do not exclude hunting activity as a factor linked to HEV infection. However, it has significantly smaller importance when compared with other risk factors, such as professional contact with farm animals and consumption of offal from animal reservoirs. An information campaign should be organised among hunters to spread the knowledge of HEV and promote proper protective measures.

Acknowledgements The authors like to thank Bożena Kucharska for taking the blood specimens and Sylwia Kamińska, Izabela Turlik, Diana Serafin-Piotrowska who interviewed the hunters participating in the study. Special thanks to Polish Hunting Association for their kind cooperation and support. The authors wish to thank PhD Aleksander Masny for support in conducting molecular testing. We would like to thank MD Anna Zielicka-Hardy, PhD Michał Czerwiński, MVD Piotr Polański, and Milena Majewska for their comments during preparation of this article.

\section{Compliance with ethical standards}

All procedures performed in studies involving human participants were in accordance with the ethical standards of the institutional research committee and with the 1964 Helsinki declaration and its later amendments or comparable ethical standards.

Conflict of interest The authors declare that they have no conflict of interest.

Ethical approval Approved by the Bioethical Commission of the National Institute of Public Health - National Institute of Hygiene in Warsaw.

Informed consent Informed consent was obtained from all individual participants included in the study.

Financial support This study was financed by National Science Centre within the funds allocated to finance research projects, Project No. N N404 520038 (Contract No. 5200/B/P01/2010/38).

Open Access This article is distributed under the terms of the Creative Commons Attribution 4.0 International License (http://creativecommons.org/licenses/by/4.0/), which permits unrestricted use, distribution, and reproduction in any medium, provided you give appropriate credit to the original author(s) and the source, provide a link to the Creative Commons license, and indicate if changes were made.

\section{References}

1. Khuroo MS, Khuroo MS (2016) Hepatitis E: an emerging global disease-from discovery towards control and cure. J Viral Hepat 23:68-79. doi:10.1111/jvh.12445

2. Marano G, Vaglio S, Pupella S, Facco G, Bianchi M, Calizzani G, Candura F, Catalano L, Farina B, Lanzoni M, Piccinini V, Liumbruno GM, Grazzini G (2015) Hepatitis E: an old infection with new implications. Blood Transfus 13:6-20. doi:10.2450/2014.0063-14

3. Pavio N, Meng X-J, Doceul V (2015) Zoonotic origin of hepatitis E. Curr Opin Virol 10:34-41. doi:10.1016/j. coviro.2014.12.006

4. Van der Poel WH (2014) Food and environmental routes of Hepatitis E virus transmission. Curr Opin Virol 4:91-96. doi:10.1016/j. coviro.2014.01.006 
5. Pawlotsky J-M (2014) Hepatitis E screening for blood donations: an urgent need? Lancet 384:1729-1730. doi:10.1016/ S0140-6736(14)61187-9

6. Schlosser B, Stein A, Neuhaus R, Pahl S, Ramez B, Krüger DH, Berg T, Hofmann J (2012) Liver transplant from a donor with occult HEV infection induced chronic hepatitis and cirrhosis in the recipient. J Hepatol 56:500-502. doi:10.1016/j. jhep.2011.06.021

7. Pourbaix A, Ouali N, Soussan P, Roque Afonso AM, Péraldi MN, Rondeau E, Peltier J (2017) Evidence of hepatitis E virus transmission by renal graft. Transpl Infect Dis. doi:10.1111/tid.12624

8. Lapa D, Capobianchi MR, Garbuglia AR (2015) Epidemiology of Hepatitis E virus in European countries. Int J Mol Sci 16:2571125743. doi:10.3390/ijms 161025711

9. Adlhoch C, Avellon A, Baylis SA, Ciccaglione AR, Couturier E, de Sousa R, Epštein J, Ethelberg S, Faber M, Fehér Á, Ijaz S, Lange H, Mand’áková Z, Mellou K, Mozalevskis A, RimhanenFinne R, Rizzi V, Said B, Sundqvist L, Thornton L, Tosti ME, van Pelt W, Aspinall E, Domanovic D, Severi E, Takkinen J, Dalton HR (2016) Hepatitis E virus: assessment of the epidemiological situation in humans in Europe, 2014/15. J Clin Virol 82:9-16. doi:10.1016/j.jcv.2016.06.010

10. Aggarwal R (2011) Clinical presentation of hepatitis E. Virus Res 161:15-22. doi:10.1016/j.virusres.2011.03.017

11. Behrendt P, Steinmann E, Manns MP, Wedemeyer H (2014) The impact of hepatitis $E$ in the liver transplant setting. J Hepatol 61:1418-1429. doi:10.1016/j.jhep.2014.08.047

12. Bazerbachi F, Haffar S, Garg SK, Lake JR (2016) Extra-hepatic manifestations associated with hepatitis $\mathrm{E}$ virus infection: a comprehensive review of the literature. Gastroenterol Rep (Oxf) 4(1):1-15. doi:10.1093/gastro/gov042

13. Hartl J, Otto B, Madden RG, Webb G, Woolson KL, Kriston L, Vettorazzi E, Lohse AW, Dalton HR, Pischke S (2016) Hepatitis E seroprevalence in Europe: a meta-analysis. Viruses. 8:211. doi:10.3390/v8080211

14. Salines M, Andraud M, Rose N (2017) From the epidemiology of hepatitis $\mathrm{E}$ virus (HEV) within the swine reservoir to public health risk mitigation strategies: a comprehensive review. Vet Res 48:31. doi:10.1186/s13567-017-0436-3

15. de Deus N, Peralta B, Pina S, Allepuz A, Mateu E, Vidal D, RuizFons F, Martín M, Gortázar C, Segalés J (2008) Epidemiological study of hepatitis E virus infection in European wild boars (Sus scrofa) in Spain. Vet Microbiol 129:163-170. doi:10.1016/j. vetmic.2007.11.002

16. De Schryver A, De Schrijver K, François G, Hambach R, van Sprundel M, Tabibi R, Colosio C (2015) Hepatitis E virus infection: an emerging occupational risk? Occup Med 65:667-672. doi:10.1093/occmed/kqv154

17. Jaroszewicz J, Flisiak R, Kalinowska A, Wierzbicka I, Prokopowicz D (2005) Acute hepatitis E complicated by acute pancreatitis: a case report and literature review. Pancreas 30:382-384. doi:10.1097/01.mpa.0000160962.06333.17

18. Jaroszewicz J, Rogalska M, Kalinowska A, Wierzbicka I, Parfieniuk A, Flisiak R (2008) Prevalence of antibodies against hepatitis E virus among students from India living in Bialystok, Poland. Przegl Epidemiol 62:433-438 PMID: 18807491

19. Bura M, Michalak M, Chojnicki M, Czajka A, Kowala-Piaskowska A, Mozer-Lisewska I (2015) Seroprevalence of anti-HEV IgG in 182 Polish patients. Postepy Hig Med Dosw 69:320-326. doi:10.5604/17322693.1143051

20. Bura M, Łagiedo M, Michalak M, Sikora J, Mozer-Lisewska I (2017) Hepatitis E virus IgG seroprevalence in HIV patients and blood donors, west-central Poland. Int J Infect Dis 61:20-22. doi:10.1016/j.ijid.2017.05.014

21. Larska M, Krzysiak MK, Jabłoński A, Kęsik J, Bednarski M, Rola J (2015) Hepatitis E virus antibody prevalence in wildlife in Poland. Zoonoses Public Health 62:105-110. doi:10.1111/ zph.1211324655475

22. Dorn-In S, Schwaiger K, Twarużek M, Grajewski J, Gottschalk C, Gareis M (2017) Hepatitis E virus in wild boar in northwest Poland: sensitivity of methods of detection. Foodborne Pathog Dis 14:103-108. doi:10.1089/fpd.2016.2194

23. Weiner M, Tokarska-Rodak M, Plewik D, Pańczuk A, Szepeluk A, Krajewska M (2016) Preliminary study on the detection of hepatitis E virus (HEV) antibodies in pigs and wild boars in Poland. J Vet Res 60:385-389. doi:10.1515/jvetres-2016-0057

24. Deutz A, Fuchs K, Nowotny N, Auer H, Schuller W, Stünzner D, Aspöck H, Kerbl U, Köfer J (2003) Sero-epidemiological studies of zoonotic infections in hunters-comparative analysis with veterinarians, farmers, and abattoir workers. Wien Klin Wochenschr 115(Suppl 3):61-67 PMID: 15508783

25. Sadkowska-Todys M, Baumann-Popczyk A, Wnukowska N, Popczyk B, Kucharczyk B, Gołąb E (2015) Occurrence and prevalence of selected zoonotic agents: Echinococcus multilocularis, Trichinella spiralis and hepatitis E virus (HEV) in the population of Polish hunters - results of the study conducted in 2010-2012. Przeglạd Epidemiol 69:673-678 (PMID: 27139343)

26. Toyoda K, Furusyo N, Takeoka H, Murata M, Sawayama Y, Hayashi J (2008) Epidemiological study of hepatitis $\mathrm{E}$ virus infection in the general population of Okinawa, Kyushu, Japan. J Gastroenterol Hepatol 23:1885-1890. doi:10.1111/j.1440-1746.2008.05568.x

27. Mansuy JM, Legrand-Abravanel F, Calot JP, Peron JM, Alric L, Agudo S, Rech H, Destruel F, Izopet J (2008) High prevalence of anti-hepatitis $\mathrm{E}$ virus antibodies in blood donors from South West France. J Med Virol 80:289-293. doi:10.1002/jmv.21056

28. Montagnaro S, De Martinis C, Sasso S, Ciarcia R, Damiano S, Auletta L, Iovane V, Zottola T, Pagnini U (2015) Viral and antibody prevalence of hepatitis E in European Wild Boars (Sus scrofa) and hunters at zoonotic risk in the Latium region. J Comp Pathol 153:1-8. doi:10.1016/j.jcpa.2015.04.006

29. Teixeira J, Mesquita JR, Pereira SS, Oliveira RM, Abreu-Silva J, Rodrigues A, Myrmel M, Stene-Johansen K, Øverbø J, Gonçalves G, Nascimento MS (2017) Prevalence of hepatitis E virus antibodies in workers occupationally exposed to swine in Portugal. Med Microbiol Immunol 206:77-81. doi:10.1007/s00430-016-0484-8

30. Thiry D, Mauroy A, Saegerman C, Licoppe A, Fett T, Thomas I, Brochier B, Thiry E, Linden A (2017) Belgian wildlife as potential zoonotic reservoir of hepatitis E virus. Transbound Emerg Dis 64:764-773. doi:10.1111/tbed.12435

31. Ivanova A, Tefanova V, Reshetnjak I, Kuznetsova T, Geller J, Lundkvist A, Janson M, Neare K, Velström K, Jokelainen P, Lassen B, Hütt P, Saar T, Viltrop A, Golovljova I (2015) Hepatitis $\mathrm{E}$ virus in domestic pigs, wild boars, pig farm workers, and hunters in Estonia. Food Environ Virol 7:403-412. doi:10.1007/ s12560-015-9210-8

32. Anheyer-Behmenburg HE, Szabo K, Schotte U, Binder A, Klein G, Johne R (2017) Hepatitis E virus in wild boars and spillover infection in red and roe deer, Germany, 2013-2015. Emerg Infect Dis 23:130-133. doi:10.3201/eid2301.161169

33. Oliveira-Filho EF, Bank-Wolf BR, Thiel H-J, König M (2014) Phylogenetic analysis of hepatitis $\mathrm{E}$ virus in domestic swine and wild boar in Germany. Vet Microbiol 174:233-238. doi:10.1016/j. vetmic.2014.09.011

34. Rutjes SA, Lodder WJ, Lodder-Verschoor F, van den Berg HH, Vennema H, Duizer E, Koopmans M, de Roda Husman AM (2009) Sources of hepatitis E virus genotype 3 in the Netherlands. Emerg Infect Dis 15:381-387. doi:10.3201/eid1503.071472

35. Žele D, Barry AF, Hakze-van der Honing RW, Vengušt G, van der Poel WHM (2016) Prevalence of anti-hepatitis E virus antibodies and first detection of hepatitis E Virus in wild boar in Slovenia. Vector Borne Zoonotic Dis 16:71-74. doi:10.1089/vbz.2015.1819 
36. Roth A, Lin J, Magnius L, Karlsson M, Belák S, Widén F, Norder $\mathrm{H}$ (2016) Markers for ongoing or previous hepatitis $\mathrm{E}$ virus infection are as common in wild ungulates as in humans in Sweden. Viruses 8(9):259 (pii: E259. PMID: 27657108)

37. Mazzei M, Nardini R, Verin R, Forzan M, Poli A, Tolari F (2015) Serologic and molecular survey for hepatitis $\mathrm{E}$ virus in wild boar (Sus scrofa) in Central Italy. New Microbes New Infect 7:41-47. doi:10.1016/j.nmni.2015.05.008

38. Mesquita JR, Oliveira RMS, Coelho C, Vieira-Pinto M, Nascimento MSJ (2016) Hepatitis E virus in sylvatic and captive wild boar from Portugal. Transbound Emerg Dis 63:574-578. doi:10.1111/tbed.12297

39. Schlosser J, Vina-Rodriguez A, Fast C, Groschup MH, Eiden M (2015) Chronically infected wild boar can transmit genotype 3 hepatitis E virus to domestic pigs. Vet Microbiol 180:15-21. doi:10.1016/j.vetmic.2015.08.022

40. Martinelli N, Pavoni E, Filogari D, Ferrari N, Chiari M, Canelli E, Lombardi G (2015) Hepatitis E virus in wild boar in the central northern part of Italy. Transbound Emerg Dis 62:217-222. doi:10.1111/tbed.12118

41. Schielke A, Ibrahim V, Czogiel I, Faber M, Schrader C, Dremsek P, Ulrich RG, Johne R (2015) Hepatitis E virus antibody prevalence in hunters from a district in Central Germany, 2013: a crosssectional study providing evidence for the benefit of protective gloves during disembowelling of wild boars. BMC Infect Dis 15:440. doi:10.1186/s12879-015-1199-y

42. Sommerkorn FM, Schauer B, Schreiner T, Fickenscher H, Krumbholz A (2017) Performance of hepatitis E Virus (HEV)antibody tests: a comparative analysis based on samples from individuals with direct contact to domestic pigs or wild boar in Germany. Med Microbiol Immunol 206:277-286. doi:10.1007/ s00430-017-0503-4

43. Olsen B, Axelsson-Olsson D, Thelin A, Weiland O (2006) Unexpected high prevalence of $\mathrm{IgG}$-antibodies to hepatitis $\mathrm{E}$ virus in Swedish pig farmers and controls. Scand J Infect Dis 38:55-58. doi:10.1080/00365540500321470

44. Vulcano A, Angelucci M, Candelori E, Martini V, Patti AM, Mancini C, Santi AL, Calvani A, Casagni L, Lamberti A (2007) HEV prevalence in the general population and among workers at zoonotic risk in Latium region. Ann Ig 19:181-186 PMID: 17658105

45. Krumbholz A, Joel S, Dremsek P, Neubert A, Johne R, Dürrwald R, Walther M, Müller TH, Kühnel D, Lange J, Wutzler P, Sauerbrei A, Ulrich RG, Zell R (2014) Seroprevalence of hepatitis $\mathrm{E}$ virus (HEV) in humans living in high pig density areas of Germany. Med Microbiol Immunol 203:273-282. doi:10.1007/ s00430-014-0336-3

46. Lange H, Øverbø J, Borgen K, Dudman S, Hoddevik G, Urdahl AM, Vold L, Sjurseth SK (2017) Hepatitis E in Norway: seroprevalence in humans and swine. Epidemiol Infect 145:181-186. doi:10.1017/S0950268816002144

47. Bouwknegt M, Frankena K, Rutjes SA, Wellenberg GJ, de Roda Husman AM, van der Poel WH, de Jong MC (2008) Estimation of hepatitis $\mathrm{E}$ virus transmission among pigs due to contact-exposure. Vet Res 39:40. doi:10.1051/vetres:2008017

48. Kantala T, Kinnunen PM, Oristo S, Jokelainen P, Vapalahti O, Maunula L (2017) Hepatitis E virus antibodies in Finnish Veterinarians. Zoonoses Public Health 64:232-238. doi:10.1111/ zph. 12312

49. Ijaz S, Vyse AJ, Morgan D, Pebody RG, Tedder RS, Brown D (2009) Indigenous hepatitis E virus infection in England: more common than it seems. J Clin Virol 44:272-276. doi:10.1016/j. jcv.2009.01.005

50. Slot E, Hogema BM, Riezebos-Brilman A, Kok TM, Molier M, Zaaijer HL (2013) Silent hepatitis E virus infection in Dutch blood donors, 2011 to 2012. Euro Surveill. doi:10.2807/1560-7917. ES2013.18.31.20550
51. Mansuy JM, Gallian P, Dimeglio C, Saune K, Arnaud C, Pelletier B, Morel P, Legrand D, Tiberghien P, Izopet J (2016) A nationwide survey of hepatitis $\mathrm{E}$ viral infection in French blood donors. Hepatology 63(4):1145-1154. doi:10.1002/hep.28436

52. Verhoef L, Koopmans M, Duizer E, Bakker J, Reimerink J, Van Pelt W (2012) Seroprevalence of hepatitis E antibodies and risk profile of HEV seropositivity in The Netherlands, 2006-2007. Epidemiol Infect 140:1838-1847. doi:10.1017/S0950268811002913

53. Yoon Y, Jeong HS, Yun H, Lee H, Hwang YS, Park B, Lee CJ, Lee S, Hyeon JY (2014) Hepatitis E Virus (HEV) seroprevalence in the general population of the Republic of Korea in 2007-2009: a nationwide cross-sectional study. BMC Infect Dis 14:517. doi:10.1186/1471-2334-14-517

54. Renou C, Moreau X, Pariente A, Cadranel JF, Maringe E, Morin T, Causse X, Payen JL, Izopet J, Nicand E, Bourlière M, Penaranda G, Hardwigsen J, Gerolami R, Péron JM, Pavio N, ANGH, France (2008) A national survey of acute hepatitis E in France. Aliment Pharmacol Ther 27:1086-1093. doi:10.1111/j.1365-2036.2008.03679.x

55. Tei S, Kitajima N, Takahashi K, Mishiro S (2003) Zoonotic transmission of hepatitis $\mathrm{E}$ virus from deer to human beings. Lancet 362:371-373. doi:10.1016/S0140-6736(03)14025-1

56. Li TC, Chijiwa K, Sera N, Ishibashi T, Etoh Y, Shinohara Y, Kurata Y, Ishida M, Sakamoto S, Takeda N, Miyamura T (2005) Hepatitis E virus transmission from wild boar meat. Emerg Infect Dis 11:1958-1960. doi:10.3201/eid1112.051041

57. Masuda J, Yano K, Tamada Y, Takii Y, Ito M, Omagari K, Kohno S (2005) Acute hepatitis E of a man who consumed wild boar meat prior to the onset of illness in Nagasaki, Japan. Hepatol Res 31:178-183. doi:10.1016/j.hepres.2005.01.008

58. Rivero-Juarez A, Frias M, Martinez-Peinado A, Risalde MA, Rodriguez-Cano D, Camacho A, García-Bocanegra I, Cuenca-Lopez F, Gomez-Villamandos JC, Rivero A (2017) familial hepatitis E outbreak linked to wild boar meat consumption. Zoonoses Public Health. doi:10.1111/zph.12343

59. Giordani MT, Fabris P, Brunetti E, Goblirsch S, Romanò L (2013) Hepatitis E and lymphocytic leukemia in Man, Italy. Emerg Infect Dis 19:2054-2056. doi:10.3201/eid1912.130521

60. Wichmann O, Schimanski S, Koch J, Kohler M, Rothe C, Plentz A, Jilg W, Stark K (2008) Phylogenetic and case-control study on hepatitis E virus infection in Germany. J Infect Dis 198:17321741. doi:10.1086/593211

61. Barnaud E, Rogée S, Garry P, Rose N, Pavio N (2012) Thermal inactivation of infectious hepatitis $\mathrm{E}$ virus in experimentally contaminated food. Appl Environ Microbiol 78:5153-5159. doi:10.1128/AEM.00436-12

62. Lewis HC, Boisson S, Ijaz S, Hewitt K, Ngui SL, Boxall E, Teo CG, Morgan D (2008) Hepatitis E in England and Wales. Emerg Infect Dis 14:165-167. doi:10.3201/eid1401.070307

63. Kuno A, Ido K, Isoda N, Satoh Y, Ono K, Satoh S, Inamori H, Sugano K, Kanai N, Nishizawa T, Okamoto H (2003) Sporadic acute hepatitis $\mathrm{E}$ of a 47 -year-old man whose petcat was positive for antibody to hepatitis E virus. Hepatol Res 26:237-242. doi:10.1016/S1386-6346(03)00197-9

64. Okamoto H, Takahashi M, Nishizawa T, Usui R, Kobayashi E (2004) Presence of antibodies to hepatitis E virus in Japanese pet cats. Infection 32:57-58. doi:10.1007/s15010-004-3078-0

65. Lagler H, Poeppl W, Winkler H, Herkner H, Faas A, Mooseder G, Burgmann H (2014) Hepatitis E virus seroprevalence in Austrian adults: a nationwide cross-sectional study among civilians and military professionals. PLoS ONE 9:e87669. doi:10.1371/journal. pone.0087669

66. Mesquita JR, Valente-Gomes G, Conceição-Neto N, Nascimento MS (2014) Pet veterinarians have no increased risk of hepatitis E compared to the general population. J Med Virol 86:954-956. doi:10.1002/jmv.23927 
67. Chaussade H, Rigaud E, Allix A, Carpentier A, Touzé A, Delzescaux D, Choutet P, Garcia-Bonnet N, Coursaget P (2013) Hepatitis $\mathrm{E}$ virus seroprevalence and risk factors for individuals in working contact with animals. J Clin Virol 58:504-508. doi:10.1016/j. jcv.2013.08.030

68. Dalton HR, Bendall R, Ijaz S, Banks M (2008) Hepatitis E: an emerging infection in developed countries. Lancet Infect Dis 8:698-709. doi:10.1016/S1473-3099(08)70255-X

69. Krain LJ, Nelson KE, Labrique AB (2014) Host immune status and response to hepatitis $\mathrm{E}$ virus infection. Clin Microbiol Rev 27:139-165. doi:10.1128/CMR.00062-13

70. Vollmer T, Diekmann J, Eberhardt M, Knabbe C, Dreier J (2016) Hepatitis $\mathrm{E}$ in blood donors: investigation of the natural course of asymptomatic infection, Germany, 2011. Euro Surveill. doi:10.2807/1560-7917.ES.2016.21.35.30332

71. Pas SD, Streefkerk RH, Pronk M, de Man RA, Beersma MF, Osterhaus AD, van der Eijk AA (2013) Diagnostic performance of selected commercial HEV IgM and IgG ELISAs for immunocompromised and immunocompetent patients. J Clin Virol 58:629-634. doi:10.1016/j.jcv.2013.10.010

72. Vollmer T, Diekmann J, Eberhardt M, Knabbe C, Dreier J (2016) Monitoring of anti-hepatitis $\mathrm{E}$ virus antibody seroconversion in asymptomatically infected blood donors: systematic comparison of nine commercial anti-HEV IgM and IgG assays. Viruses. doi: $10.3390 / \mathrm{v} 8080232$ 